\title{
POINTER YEARS IN TREE-RING WIDTH OF EUROPEAN ASH WITH DIFFERENT CROWN CONDITION AND THEIR RELATIONSHIPS WITH CLIMATIC FACTORS IN LATVIA
}

\author{
Roberts Matisons ${ }^{1 \#}$, Linda Gerra Inohosa ${ }^{1}$, and Māris Laiviṇš ${ }^{1,} 2$ \\ ${ }^{1}$ Latvian State Forest Research Institute "Silava", Rīgas iela 111, Salaspils, LV-2169, LATVIA \\ ${ }^{2}$ Forest Sector Competence Centre, Dzērbenes iela 23, Rīga, LV-1006, LATVIA \\ \# Corresponding author; robism@inbox.lv
}

Communicated by Āris Jansons

\begin{abstract}
The effect of climatic factors on tree-ring width (TRW) of European ash (Fraxinus excelsior L.) with healthy and damaged crowns growing in the central and eastern part of Latvia was assessed by dendrochronological techniques. Pointer year indices were calculated to assess the variability of TRW. Positive pointer years were more frequent than negative, similarly for damaged and healthy trees, suggesting similar limiting factors. The relationships between TRW and climatic factors differed regionally and locally. In the eastern part of Latvia, TRW was affected by temperature in spring of current and preceding years. In the central part of Latvia, weather conditions in current and preceding summer mainly affected TRW; temperature and precipitation had positive effect suggesting occurrence of water deficit, but the daily range of temperature had a negative effect. Hence, regional diversification of radial growth patterns might be expected. Some differences in sensitivity to climate were observed between the damaged and healthy trees. In the central part of Latvia, the damaged trees appeared additionally sensitive to temperature in summer. In the eastern part of Latvia, damaged trees were additionally sensitive to temperature in May. Nevertheless, some additional factors were significant for the healthy trees.
\end{abstract}

Key words: Fraxinus excelsior, radial increment, weather conditions, ash dieback.

\section{INTRODUCTION}

The climate-induced changes in the distribution of tree species are considered to cause gradual replacement due to altered competition conditions and hence recruitment (Hickler et al., 2012). Nevertheless, the effect of climatic changes might be indirect, i.e. through pest activity (La Porta et al., 2008), which might cause dieback of a certain species (Bartos and Campbell, 1998; Bakys et al., 2011), and hence accelerate the changes. Dieback of ash (Fraxinus excelsior L.) has been reported from many sites in Europe (Kowalski, 2006; Kirisits and Freinschlag, 2011; Timmermann et al., 2011), and it is considered to be a result of interaction between the climatic factors and pests (Pautasso et al., 2010; Skovsgaard et al., 2010). The fungus Hymenosciphus fraxineus has been mentioned as one of the main causes of dieback (Kowalski, 2006). It infects stressed trees, e.g. by climatic factors causing drought or heat stress (Thomsen and Skovsgaard, 2006; Pautasso et al., 2010). It affects roots, decreasing the stability of the tree and altering water relations (Bakys et al., 2008; Tulik et al., 2010). Dieback of ash is a quick process, as tree death can occur a few years after the first symptoms, such as crown reduction, are observed
(Bakys et al., 2008; Timmermann et al., 2011; Enderle et al., 2013). In some cases, visual symptoms might even be lacking (Enderle et al., 2013). The intensity and development of the symptoms differ among trees (Kirisits and Freinschlag, 2011), suggesting different predisposition to the diseases (Pliūra et al., 2011). Considering that climatic factors (i.e. climatic extremes) are involved in the dieback of ash (Pautasso et al., 2010; Skovsgaard et al., 2010), knowledge about its climatic sensitivity might be crucial for the further management of the species. For pedunculate oak, the declining trees have been more sensitive than healthy trees to diverse factors, and have had diverse growth patterns already before the decline (Helama et al., 2009).

The vigour of tree, which is influenced by environmental factors, including weather and microtopography, affects growth causing variation of annual increment (Speer, 2010). Hence, detailed information about tree increment and its sensitivity to climatic factors might be obtained by retrospective analysis of stem increment, i.e. tree-ring width (TRW) (Speer, 2010). Such information is usually obtained from the analysis of TRW chronologies, the analysis of which usually diminishes the extent of extreme growth 
events (Cook et al., 1992). Nevertheless, even a short period of extreme (anomalous) weather can have a strong and lasting effect on tree vigour and hence the increment (Schweingruber, 1992; Neuwirth et al., 2004). Thus, specific standardization of time series of TRW has been developed to highlight and quantify extreme growth events, in order to study their relationship with environmental factors (Schweingruber, 1992).

The aim of this study was to determine the relationship of pointer years in TRW of ash with climatic factors (weather conditions) for trees with contrasting crown conditions. We hypothesized that the damaged trees have been more sensitive to weather conditions and anomalies compared to trees with a healthy crown.

\section{MATERIALS AND METHODS}

Study area and sampling. Four stands with ash as a codominant species were studied; two stands were located in the central part of Latvia near Rundāle (RND) and Ukri (UKR) and two stands in the eastern part of Latvia near Barkava (BAR) and Gulbene (GBN) (Fig. 1). All stands were growing on a flat terrain in normal moisture conditions on loamy soils, in Aegopodiosa (Bušs, 1976) forest type. The elevation of the stands was ca. 45 and 120 metres above sea level in the sites in the central and eastern parts of Latvia. The stands were not even-aged; the maximum age of ash in the stands, as determined from the wood samples was ca. 70, 190, 110, and 100 years in the BAR, GBN, RND and UKR sites, respectively.

The climate in the studied territories is mild due to dominant western winds, which bring cool and moist air masses from the Baltic Sea and from the Atlantic. The continentality increases eastwards with the growing distance from the sea. In the central and eastern part of Latvia, mean annual temperature is ca. +6.4 and $+5.5^{\circ} \mathrm{C}$; mean monthly temperature ranges from -4.3 to $+17.5{ }^{\circ} \mathrm{C}$ and from -6.2 to +17.4 ${ }^{\circ} \mathrm{C}$ in January and July, respectively. The vegetation period with diurnal temperature above $+5{ }^{\circ} \mathrm{C}$ extends from mid-April to mid-October; however, it is usually ten days longer in central Latvia. Mean annual precipitation is about

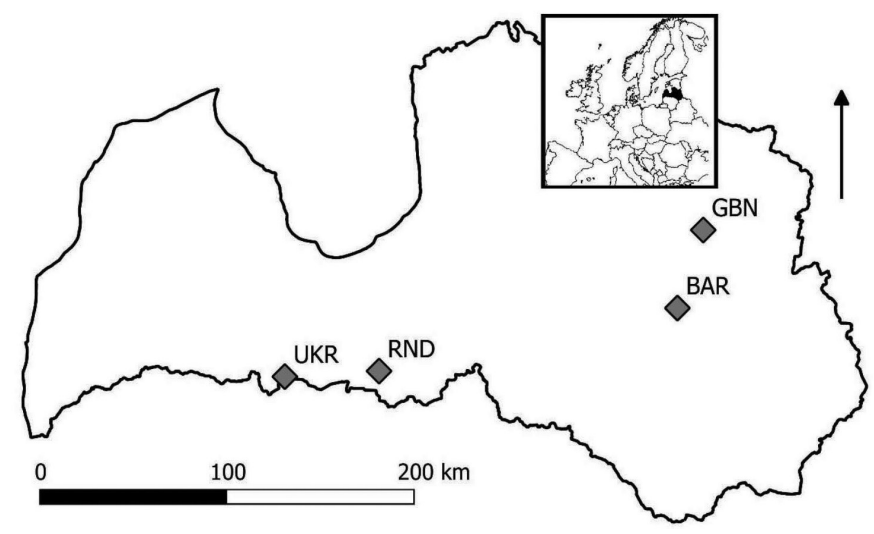

Fig. 1. Location of studied sites near Barkava (BAR), Gulbene (GBN), Rundāle (RND), and Ukri (UKR).
$610 \mathrm{~mm}$. Mean monthly precipitation is the highest during summer months, resulting in a positive water balance. Global climatic change has resulted in an increase of temperature in the autumn-spring period (Lizuma et al., 2007) and as an increase of variability of summer precipitation regime and heat events (Avotniece et al., 2010).

Ten dominant ash trees with healthy (damage $\leq 15 \%$ ) and ten trees with damaged (damage from 30-60\%) crowns were selected from each stand. This sample size has been sufficient for other species (Matisons et al., 2012). From each tree, two increment cores from opposite sides of the stem at 1.3 height were sampled with a Pressler increment corer. Sampling was conducted at the end of May 2015, when the leaves had fully flushed. In the laboratory, airdried cores were mounted on fixation planks and gradually sanded, decreasing roughness of the sandpaper from 120 to 400 grains per inch, using a hand-sanding machine. Since some of the tree-rings were narrow, the cores were rubbed with a white crayon to increase the contrast and hence the tree-ring borders. The width of tree-rings was measured manually using a Lintab 5 measurement system (RinnTECH, Heidelberg, Germany) with the accuracy of $0.01 \mathrm{~mm}$.

Data analysis. The measured time series of TRW were crossdated and their quality was verified by graphical inspection and using the software COFECHA (GrissinoMayer, 2001). Data from the healthy ashes were used as a reference to crossdate TRW series of the damaged trees. Time series that showed low agreement (correlation with the rest of dataset $<0.35$ ), were rejected from further analysis rather than corrected. For the description of the crossdated datasets, interseries correlation, first order autocorrelation, mean sensitivity, Gleichläufigkeit (GLK), expressed population signal (EPS) and signal to noise ratio (SNR) (Wigley et al., 1984) indices were calculated in the program R (Anonymous, 2014) using the library "dplR" (Bunn, 2008).

To assess abrupt changes in TRW, pointer year indices for each stand were calculated for the common period from 1935 to 2012, separately for the healthy and damaged trees (except for the healthy trees in RND, where time series began from 1948). The calculation of the pointer year indices was based on a modified skeleton plot method as suggested by Neuwirth et al. (2004). The relative differences $\Delta i=\left(x_{i}-\bar{x}_{i-5 . i-1}\right) / \bar{x}_{i-5 . i-1}$ of TRW were calculated for each year (i), with respect to the mean value of the previous 5 -year period. The relative differences were expressed as scores ranging from -5 to +5 (except 0 ) in $20 \%$ steps. A score of -5 corresponded to a relative difference of $<-80 \%$, and a score of +5 to a difference of $>+80 \%$. The pointer year indices for a group of trees was calculated as follows: $I=100 / k n \sum_{j=1}^{k} h_{j} s_{j}$, where $\mathrm{k}$ - number of possible score values (10), $\mathrm{n}-$ number of trees included in the calculation, $\mathrm{h}$ - number of trees with each score, $\mathrm{s}$ - frequency of score. The pointer year indices I > 30 were arbitrarily considered as significant. 
STATISTICS OF THE CROSSDATED DATASETS OF TREE-RING WIDTH OF ASH WITH THE DAMAGED AND HEALTHY CROWNS IN SITES BEAR BARKAVA, GULBENE, RUNDĀLE AND UKRI

\begin{tabular}{|c|c|c|c|c|c|c|c|c|c|c|c|c|}
\hline & $\mathrm{N}$ & $\begin{array}{c}\text { Covered } \\
\text { period }\end{array}$ & $\begin{array}{c}\text { Min. TRW, } \\
\mathrm{mm}\end{array}$ & $\begin{array}{c}\text { Max. } \\
\text { TRW, mm }\end{array}$ & $\begin{array}{c}\text { Mean } \\
\text { TRW, mm } \\
\end{array}$ & \begin{tabular}{|c|} 
St. dev. \\
TRW, mm
\end{tabular} & $\mathrm{S}$ & IC & $\mathrm{AC}$ & GLK & EPS & SNR \\
\hline \multicolumn{13}{|c|}{ Barkava (BAR) } \\
\hline Healthy & 8 & 1933-2014 & 0.68 & 5.69 & 2.53 & 0.90 & 0.20 & 0.39 & 0.70 & 0.63 & 0.79 & 3.67 \\
\hline Damaged & 10 & 1928-2014 & 0.10 & 10.00 & 1.99 & 0.99 & 0.22 & 0.09 & 0.80 & 0.58 & 0.42 & 0.71 \\
\hline \multicolumn{13}{|c|}{ Gulbene (GBN) } \\
\hline Healthy & 10 & 1824-2014 & 0.17 & 5.39 & 1.48 & 0.61 & 0.18 & 0.31 & 0.77 & 0.60 & 0.72 & 2.53 \\
\hline Damaged & 10 & 1831-2014 & 0.12 & 4.77 & 1.38 & 0.56 & 0.19 & 0.23 & 0.79 & 0.58 & 0.69 & 2.20 \\
\hline \multicolumn{13}{|c|}{ Rundāle (RND) } \\
\hline Healthy & 9 & 1948-2014 & 0.46 & 6.24 & 2.05 & 0.81 & 0.21 & 0.36 & 0.73 & 0.60 & 0.82 & 4.49 \\
\hline Damaged & 10 & 1916-2014 & 0.16 & 6.35 & 1.79 & 0.88 & 0.19 & 0.36 & 0.83 & 0.60 & 0.83 & 4.90 \\
\hline \multicolumn{13}{|c|}{ Ukri (UKR) } \\
\hline Healthy & 7 & 1933-2014 & 0.53 & 5.28 & 1.99 & 0.99 & 0.19 & 0.40 & 0.86 & 0.60 & 0.81 & 4.32 \\
\hline Damaged & 8 & 1925-2014 & 0.20 & 5.80 & 1.65 & 0.89 & 0.17 & 0.44 & 0.87 & 0.64 & 0.85 & 5.73 \\
\hline
\end{tabular}

TRW, tree-ring width; S, mean sensitivity; N, number of crossdated trees; IC, mean interseries correlation; AC, autocorrelation; GLK, Gleichläufigkeit; EPS, expressed population signal; SNR, signal to noise ratio

The effect of climatic factors on the abrupt changes in TRW of ash of different crown condition was determined by a bootstrapped Pearson correlation analysis based on the entire series of pointer year indices. The significance of the correlations was determined at $p=0.05$. The tested climatic factors were the minimum, maximum, mean temperature, mean daily temperature range, potential evapotranspiration (PET) and the precipitation sums for months. The climatic window from January of the year preceding formation of the tree-ring to September of the year of the tree-ring formation was used. Local climatic data were obtained from the high resolution gridded datasets provided by the Climatic Research Unit of UEA (Harris et al., 2014) for grid units containing the sampling sites. Collinearity of the significant factors was assessed, and only one of the collinear factors having the strongest correlation with pointer year indices was shown and discussed. To identify weather anomalies i.e. years with extreme values of climatic data, $z$-scores were calculated for each climatic factor.

\section{RESULTS}

From 75 to $100 \%$ of the measured time series of trees per sites and groups (damaged or healthy) passed the crossdating and the quality checking and were used for further analysis (Table 1). The crossdated datasets covered the periods beginning from 1824 to 1948 in the GBN and RND sites. The damaged trees were generally older then the healthy trees. Autocorrelation for TRW was higher in damaged trees than in healthy trees $(0.82$ and 0.77 , respectively). The healthy trees showed better agreement of high-frequency variation of TRW in the sites in eastern Latvia, as shown by higher values of the interseries correlation, Gleichläufigkeit and the expressed population signal, but the opposite was observed in the sites in central Latvia. The environmental signals in TRW were stronger in central than in eastern Latvia, where the mean values of signal to noise ratio were 4.8 and 2.3 , respectively. The damaged trees in the BAR site had the weakest agreement (expressed population signal was 0.42 ), which that was shown by the lowest signal to noise ratio of 0.72 amongst the datasets. The value of the expressed population signal was above 0.80 for datasets from the sites in central Latvia, but it reached 0.85 only for the damaged trees in the UKR site.

The pointer year indices ranged from -69 to 100 , but the range was slightly narrower for trees from central than eastern Latvia (from -69 to 70 and from -60 to 100 , respectively) (Fig. 2). The range tended to decrease with increasing sampling depth and age. The variation of index values was smooth and periodic; nevertheless, several outstanding pointer years, e.g., in 1943 (UKR), 1956 (GBN healthy), 1978 (BAR, health) and 1988 (BAR, damaged) were observed. The teleconnection between the sites was rather weak, as mean value of the correlation coefficients calculated between the index series was ca. 0.25 , suggesting individuality of growth variation, although pointer year indices of damaged trees in the RND and UKR were quite similar $(r=0.70)$. The correlation of index series amongst the healthy and damaged trees within a stand was above 0.60 in the GBN, RND and UKR sites; however, it was only 0.28 in the BAR site.

The occurrence of significant pointer years, i.e. years with the absolute index value above 30 , differed between the regions and groups of trees (Fig. 2). In total, 65 and 66 years with absolute index I > 30 were observed in sites in central and eastern Latvia, but none of the significant pointer years co-occurred for all sites/groups. However, positive pointer years were more frequent than the negative years (77 and 54 , respectively), particularly in the BAR site where 31 positive and 12 negative pointer years were observed. The highest and lowest numbers of significant pointer years 


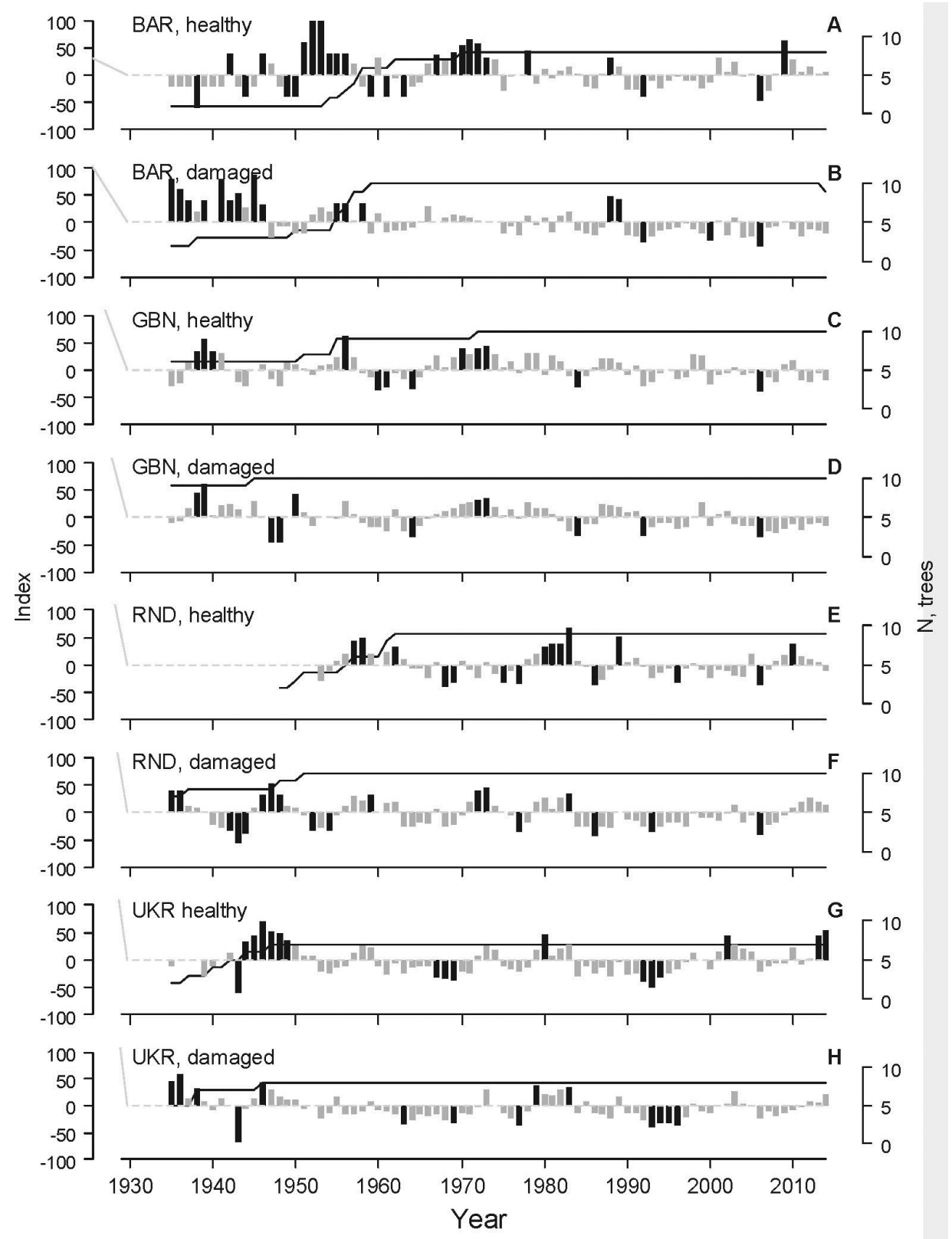

Fig. 2. Pointer year index values (bars) and sample depth (thin line) of tree-ring width (TRW) of ash with healthy (A, C, E, G) and damaged (B, D, F, H) crowns for sites near Barkava (BAR), Gulbene (GBN), Rundāle (RND) and Ukri (UKR), respectively. Indices are based on crossdated datasets. Pointer years exceeding \pm 30 are in black. For GBN site, only data for the common period from 1935 to 2014 are shown.

were observed in sites in eastern Latvia - for the healthy trees in the BAR site (26) and for the damaged trees in GBN site (11). In eastern Latvia, the number of significant pointer years was higher for healthy trees, while similar number of years was observed for both tree groups in eastern Latvia. The highest and the lowest mean values of the significant pointer year indices were observed for healthy trees in the BAR site and for the damaged trees in the RND site, ca. 49 and 39, respectively. Nevertheless, in general, the significant pointer years had higher values in the sites in eastern that in central Latvia (ca. 46 and 41, respectively).

The time series of pointer year values were significantly correlated with 18 of the 132 tested climatic factors (Fig. 3). The coefficient values of the significant correlations were mainly low or intermediate $(r \leq 0.43)$. The sets of the significant climatic factors differed regionally and among the trees with different crown condition, yet there was some individuality amongst the sites and groups. In the sites in east- ern Latvia, pointer year indices correlated with temperature and its monthly range in spring of the year of tree-ring formation in the preceding year. Additionally, some correlations with precipitation related factors in winter of current and preceding year were observed. In both sites, the healthy trees showed sensitivity to precipitation in January, but the damaged trees showed some sensitivity to temperature in May. In the BAR site, healthy trees showed a lower number of significant factors than the damaged trees (two and six, respectively) and the correlations were weaker (mean $r$ was 0.25 and 0.36 ). The damaged trees showed the highest sensitivity to temperature in April. In contrast, in the GBN site, pointer years of damaged trees were weaker correlated with the climatic factors (mean $r$ was 0.23 and 0.32 , respectively), although the number of the significant factors was higher compared to the healthy trees (eight and six).

In the sites in central Latvia, pointer year indices were mainly correlated with weather conditions in the preceding 


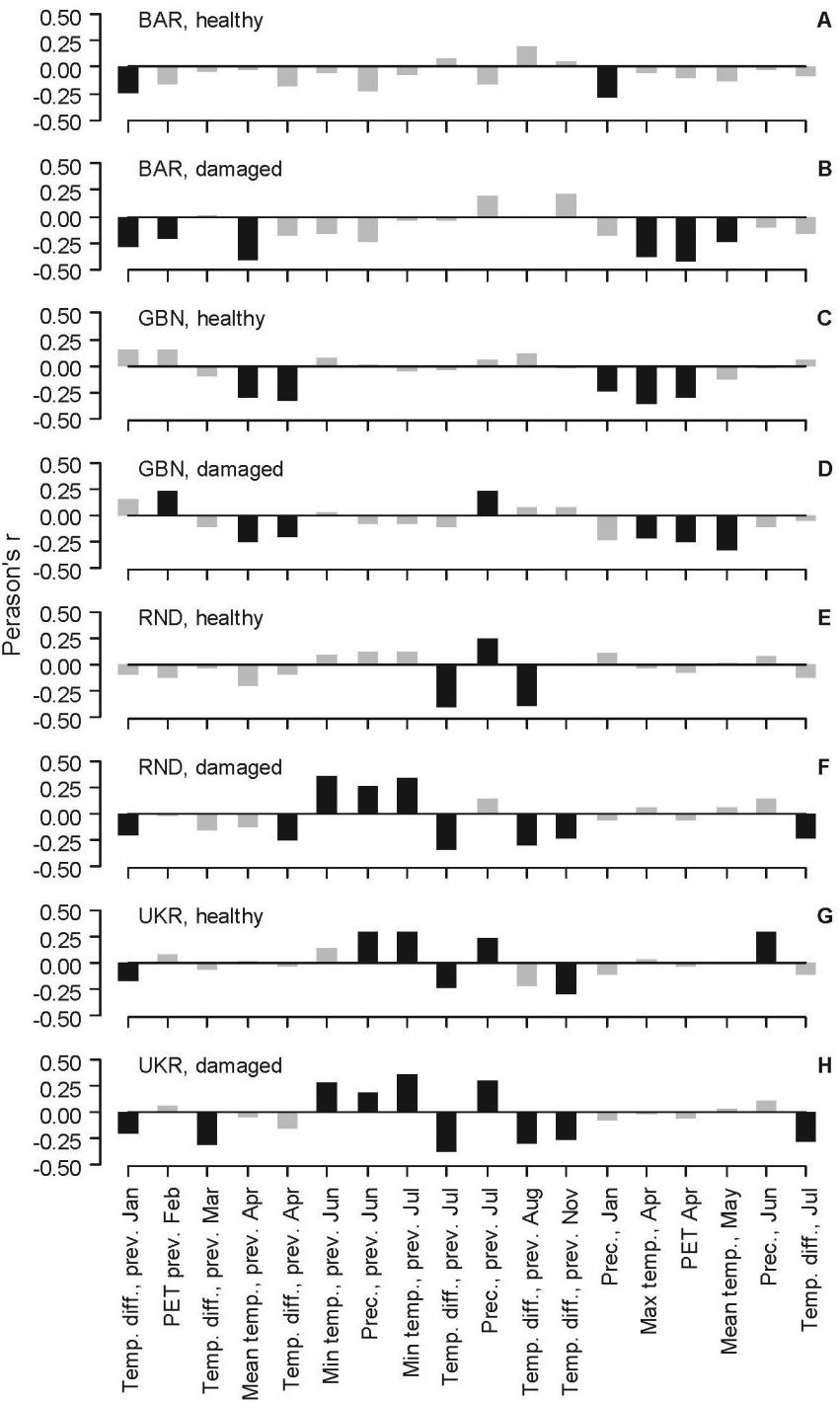

Fig. 3. Bootstrapped Pearson's correlation coefficients calculated between climatic factors and pointer year indices of tree-ring width of ash with healthy (A, C, E, G) and damaged crowns $(\mathrm{B}, \mathrm{D}, \mathrm{F}, \mathrm{H})$ for sites near Barkava (BAR), Gulbene (GBN), Rundāle (RND), and Ukri (UKR), respectively. The significant correlations are shown in black. Only the significant factors are plotted. PET - potential evapotranspiration, prec. precipitation, temp. - temperature.

and current summer (Fig. 3). Summer temperature and precipitation had a positive correlation, while the range of temperature had a negative correlation with index values. In both sites, the damaged trees showed sensitivity to the minimum temperature in June of the preceding year and monthly range of temperature in the current July. Nevertheless, some differences in the sets of the significant factors were site specific. In the RND site, the number of significant factors was lower (three and nine), but the values of significant correlation coefficients were higher (mean $\mathrm{r}$ was 0.37 and 0.29 ) for the healthy than the damaged trees. Higher number of the significant factors was also observed for the damaged trees in the UKR site, yet the strength of correlations was similar. In the UKR site, the damaged trees were more sensitive to temperature and precipitation in July of the year
YEARS WITH POINTER YEAR VALUES EXCEEDING \pm 30 IN SITES IN CENTRAL AND EASTERN LATVIA IN TREE-RING WIDTH OF ASH WITH HEALTHY AND DAMAGED CROWNS AND THE RELEVANT WEATHER ANOMALIES

\begin{tabular}{|c|c|c|c|c|c|}
\hline \multirow[t]{2}{*}{ Year } & \multicolumn{2}{|c|}{ Central Latvia } & \multicolumn{2}{|c|}{ Eastern Latvia } & \multirow{2}{*}{$\begin{array}{l}\text { Related meteoro- } \\
\text { logical anomaly }\end{array}$} \\
\hline & Healthy & Damaged & Healthy & Damaged & \\
\hline 1935 & & $\mathrm{P}$ & & & $\begin{array}{l}\text { warm SEP }(+2.6) \text {, } \\
\text { moist Jun }(+2.2)\end{array}$ \\
\hline 1936 & & $\mathrm{P}$ & & & moist JUN (+2.2) \\
\hline 1939 & & & & $\mathrm{P}$ & $\begin{array}{l}\text { moist OCT }(+2.8) \text {, } \\
\text { warm AUG }(+2.8) \text {, } \\
\text { Aug }(+2.7)\end{array}$ \\
\hline 1943 & $\mathrm{~N}$ & $\mathrm{~N}$ & & & $\begin{array}{l}\text { cold JAN }(-2.5) \\
\operatorname{MAR}(-2.8)\end{array}$ \\
\hline 1944 & & & $\mathrm{~N}$ & & - \\
\hline 1946 & $\mathrm{P}$ & $\mathrm{P}$ & & & - \\
\hline 1956 & & & $\mathrm{P}$ & $\mathrm{P}$ & $\begin{array}{l}\text { dry AUG }(-2.2) \text {, } \\
\text { extr moist Apr } \\
(+4.6) \text {, cold } \\
\text { APR(-2.3), Aug } \\
(-2.2)\end{array}$ \\
\hline 1961 & & & $\mathrm{P}$ & & warm DEC $(+2.1)$ \\
\hline 1970 & & & $\mathrm{P}$ & & moist Apr $(+2.0)$ \\
\hline 1973 & & $\mathrm{P}$ & $\mathrm{P}$ & & $\begin{array}{l}\text { moist NOV }(+2.2) \text {, } \\
\text { hot JUL }(+3.1) \\
\text { cool Sep }(-2.1)\end{array}$ \\
\hline 1978 & & & $\mathrm{P}$ & & $\begin{array}{l}\text { moist APR }(+2.3) \text {, } \\
\text { Aug }(+2.4), \text { moist } \\
\operatorname{JUL}(+2.1)\end{array}$ \\
\hline 1980 & $\mathrm{P}$ & & & & $\begin{array}{l}\text { cool JUL }(-2.1) \\
\text { moist OCT }(+2.2)\end{array}$ \\
\hline 1992 & $\mathrm{~N}$ & & $\mathrm{~N}$ & $\mathrm{~N}$ & $\begin{array}{l}\text { cool OCT }(-2.3) \text {, } \\
\text { unstable temp Jun } \\
(+3.7) \text {, Jul }(+3.0) \text {, }\end{array}$ \\
\hline 2006 & & $\mathrm{~N}$ & $\mathrm{~N}$ & $\mathrm{~N}$ & $\begin{array}{l}\text { moist } \operatorname{MAY}(+2.7) \text {, } \\
\text { warm Aug }(+2.2)\end{array}$ \\
\hline
\end{tabular}

TRW, tree-ring width; P, positive pointer year; N. negative pointer year. Numbers in brackets: Z-scores of the anomalies of monthly temperature and precipitation sums, calculated for 30 year period based on the data from CRU for grid points located closest to sites. Only the anomalies with $\mid z$-scores $\mid>2$ are shown. Months, corresponding to the year preceding formation of tree-ring, are in uppercase.

preceding growth. The effect of temperature range in January of preceding year was stronger for the damaged trees.

Amongst the strongest pointer years (absolute index value $>$ 30 ), several co-occurred for the damaged or healthy trees in both sites from the same region and it was possible to assign these pointer years with certain weather anomalies (Table 2). The common pointer years mainly occurred when a few anomalies coincided. The common negative pointer years were associated with a lower than usual temperature in winter or autumn accompanied by a shifting temperature regime. The positive pointer years were mainly associated with a warm and moist condition before or during the formation of relevant tree-ring (e.g. April, June and July or previous autumn), as previously suggested by the correla- 
tion analysis (Fig. 3). However, the positive pointer years occurred also in 1956, when August was cool. Some of the common pointer years i.e. in 1944 and 1946, apparently, were caused by other than the tested factors.

\section{DISCUSSION}

Although most of the time series of TRW were crossdated (Table 1), this was mainly achieved by matching the signature years amongst the trees within a stand. This suggested high variability of growth patterns amongst the trees, groups and sites (Table 1, Fig. 2), as portrayed by the low values of interseries correlation, expressed population signal and signal to noise ratio (Wigley et al., 1984). Low EPS might be also attributed to low sample size, but they were much lower compared to other species (Matisons et al., 2012). Although ash in Latvia occurs near its northern limit (Anonymous, 2009), where the limiting effect of certain factors and hence common signal in TRW is expected (Speer, 2010), the differences in growth patterns (Table 1) might be explained by stressed growth. Growth of the stressed trees becomes individual due to the excessive sensitivity to microclimatic conditions (Speer, 2010). The regional differences in the agreement support this idea, as higher values of expressed population signal and signal to noise ratio were observed in sites in central Latvia where the climate is milder (Table 1). However, the agreement of the damaged trees was slightly better compared to the healthy trees (Table 1), suggesting that trees that were more sensitive to environmental factor(s) (Wigley et al., 1984) might have also been more susceptible to the damage. In eastern Latvia, where climate is harsher, particularly the damaged trees were environmentally stressed and hence showed higher variability of growth patterns (Table 1), also suggesting that the more sensitive trees have been damaged, as previously described by Pautasso et al. (2010). However, the differences in age of the damaged and the healthy trees (Table 1) suggest that the susceptibility to disease might be age-dependant. With age, maintenance costs increases (Ryan et al., 1990; Pallardy, 2008) and trees become more sensitive to environmental conditions (Carrer and Urbinati, 2004). Hence, stress conditions might occur more often, favouring the development of pathogens (La Porta et al., 2008).

The differences in sensitivity between the sites and groups were portrayed by the variation patterns of TRW. The range of the pointer year indices was wider in eastern Latvia (Fig. 2 ), suggesting that the abrupt common changes in TRW were more expressed, likely due to the harsher climate. However, the range of index values decreased with age, which might be related to a biological trend in TRW (Cook et al., 1992). The periodicity of the variation of index values (Fig. 2) might be explained by the autocorrelation present in TRW (Table 1). The significant pointer years mainly occurred when the trees were at the minimum or maximum growth phase, thus amplifying the decrease or release of growth, respectively. Still, on top of this, some outstanding pointer years were evident (Fig. 2), e.g., after extreme cold events, as in 1943, 1956 and 1988, likely due to growth releases in response to winter mortality and decrease of competition (Schweingruber, 1992).

The occurrence of the significant pointer years $(|I|>30)$ was comparable between the groups (Fig. 2), suggesting that mainly susceptibility to environmental, i.e. weather anomalies of damaged and healthy trees has been similar within a stand. However, in eastern Latvia, higher sensitivity of the damaged trees was suggested by a slightly higher number and mean values of significant pointer years. The lowest number of significant pointer years occurred in the GBN site (Fig. 2) where trees were the oldest (Table 1), thus showing weaker reaction to environmental changes. In ring-porous species, earlywood width is rather constant and latewood width mainly causes the variation of TRW (Zhang, 1997). Hence, with age, the proportion of earlywood increases, thus reducing the relative variability of TRW. More frequent occurrence of positive pointer years with index ( $|\mathrm{I}|>30$ ) (Fig. 2), likely caused by highly favourable conditions, suggested that growth has been mainly suppressed, presumably by climate, as Latvia is located near the northern limit of ash (Anonymous, 2009).

The variation of pointer year indices was significantly affected by climatic factors (Fig. 3), but the low values of correlation coefficients suggested that none of the tested factors was strictly limiting. The regional differences in the sets of significant correlations might be explained by climate (Matisons et al., 2012). In eastern Latvia where the climate is harsher, spring temperature was the main limiting factor for TRW. For ring-porous species, earlywood vessels, which are the main water conduits, are formed before bud break (Sass-Klaassen et al., 2011). Conditions during their formation influence their size (Sass-Klaassen et al., 2011) and hence water relationships during the subsequent vegetation season (Tyree and Zimmermann, 2002) affecting assimilation and growth (Berry and Downton, 1982). Increased temperature in April might initiate the active period earlier, subjecting trees to frost damage ( $\mathrm{Gu}$ et al., 2008), thus explaining the negative correlation (Fig. 3). This is also supported by the negative correlation with the temperature range. The formation of earlywood depends on stored reserves (Pallardy, 2008), explaining the effect of condition in the season preceding growth (Fig. 3). In both sites, damaged trees had more factors that were significantly correlated with pointer year indices (Fig. 3), suggesting higher sensitivity to weather conditions. However, the healthy trees in both sites were sensitive to precipitation in January, which might be related to soil freeze and fine root mortality (Tierney et al., 2001), contradicting that idea.

In central Latvia, where the winters are milder, but summers hotter, conditions in spring had weak effect on the occurrence of pointer years in TRW (Fig. 3). In contrast, climatic factors related to assimilation, particularly in preceding summer, had the strongest effect, suggesting stronger dependence of radial growth on stored reserves (Pallardy, 2008). Positive effect of temperature in the preceding June and July (Fig. 3) might be explained by increased assimila- 
tion in response to warmer temperature, particularly when water is abundant (Berry and Downton, 1982), as supported by the positive correlation with precipitation (Fig. 3). On the other hand, positive correlation with precipitation might indicate occurrence of effect of water deficit, which decreases assimilation (Berry and Downton, 1982). During the vegetation season, photosynthetic apparatus is being adjusted for a certain temperature (Berry and Downton, 1982), thus increased variability of temperature might decrease assimilation, explaining the negative correlation with temperature range (Fig. 3). The sets of significant factors differed between the trees with damaged and the healthy crowns. Damaged trees showed a higher number of the significant factors and higher values of correlation coefficients (UKR site) compared to healthy trees, suggesting higher sensitivity to climatic factors, similarly, as observed in the sites in eastern Latvia. The negative effect of temperature range in the preceding January, which was stronger for the damaged trees (Fig. 3), might be related to thawing and subsequent cold damage (Zhu et al., 2000) that might alter the allocation of resources in the following year.

The significant correlations between climatic factors and pointer year indices (Fig. 3) confirmed the assignment of some pointer years common for groups within the regions with weather anomalies (Table 2), as similar factors have been mostly involved. The occurrence of these pointer years differed regionally, as shown by the correlation analysis (Fig. 3). The common pointer years occurred when mainly the effect of a few factors was combined, suggesting that additional stimulus might be needed for the forcing of regional signatures in TRW. Nevertheless, some of the common regional pointer years were not assigned to weather anomalies (e.g. in 1944 and 1946) or the assigned anomalies contradicted results of the correlation analysis (Fig. 3) (e.g. in 1939 and 1973) probably due to the effect of other factors such as competition (Martin-Benito et al., 2008). Some differences of the common pointer years were also apparent. In eastern Latvia, the common positive pointer years were more frequent for trees with healthy crowns, likely due to faster growth (wider TRW) (Table 1), and hence cleared reaction to environment (Speer, 2010). Nevertheless, a similar number of indices was observed also in eastern Latvia.

\section{CONCLUSIONS}

Local and regional features were observed in the patterns of variation of TRW of ash suggesting the complexity of the factors affecting its growth. The pointer years in TRW were stronger and more frequent in the more continental eastern region of Latvia, suggesting stronger reaction to weather. The positive pointer years were more frequent than the negative, suggesting growth release in response to favourable weather conditions, especially to their co-occurrence. In central Latvia, the occurrence of abrupt changes in growth was positively affected by temperature in the preceding summer and autumn, suggesting that with warming, growth releases might become more frequent. In eastern Latvia, pointer year indices negatively correlated with temperature- related parameters of the preceding and current spring, suggesting that growth suppression might intensify with climate warming. The differences in the occurrence of pointer years in healthy and damaged trees were small. Generally, trees with the damaged crowns have been more sensitive to climatic factors: summer temperature in the central region and spring temperature in the eastern region.

\section{ACKNOWLEDGEMENTS}

The study was funded by the joint stock company "Latvijas Valsts Meži” project "'Ash forest destruction and regeneration in Latvia" (5.5.-5.1_0017_101_14_28) and by the Forest Sector Competence Centre project "Ecological risks of forest capital management- evaluation methods and recommendations for risk mitigation” (No L-KC-11-0004)”.

\section{REFERENCES}

Anonymous (2009). EUFORGEN. Distribution maps, Fraxinus excelsior L. Available at: http://www.euforgen.org/fileadmin/www.euforgen.org/Documents/Maps/PDF/ Fraxinus_excelsior.pdf (accessed 11.11.2015).

Anonymous (2014). R Core Team. R: A language and environment for statistical computing. R Foundation for Statistical Computing, Vienna, Austria. Available at: http://www.R-project.org/.

Avotniece, Z., Rodinov, V., Lizuma, L., Briede, A., Kḷaviņš, M. (2010). Trends in frequency of extreme climate events in Latvia. Baltica, 23, 135-148.

Bakys, R., Vasiliauskas, R., Barklund, P., Ihrmark, K., Stenlid, J. (2008). Fungal attacks to root systems and crowns of declining Fraxinus excelsior. Aktuelt fra skogforskningen, 1, 71-72.

Bakys, R., Vasiliauskas, R., Ihrmark, K., Stenlid, J., Menkis, A., Vasaitis, R. (2011). Root rot, associated fungi and their impact on health condition of declining Fraxinus excelsior stands in Lithuania. Scand. J. For. Res., 26, 128-135.

Bartos, D. L., Campbell, B. C. (1998). Decline of quaking aspen in the interior west - examples from Utah. Rangelands, 20, 17-24.

Berry, J. A., Downton, W. J. S. (1982). Environmental regulation of photosynthesis. In: Govindjee (Ed.). Photosynthesis: Development, Carbon Metabolism and Plant Productivity. Academic Press, New York, pp. 265-345.

Bunn, A. G. (2008). A dendrochronology program library in R (dplR). Dendrochronologia, 26, 115-124.

Bušs, K. (1976). Latvijas PSR mežu klasifikācijas pamati [Basis of Forest Classification in the Latvian SSR]. Silava, Rīga. 34 pp. (in Latvian).

Carrer, M., Urbinati, C. (2004). Age-dependent tree-ring growth response to climate in Larix decidua and Pinus cembra. Ecology, 85, 730-740.

Cook, E. R., Briffa, K., Shiyatov, S., Mazepa, V. (1992). Tree-ring standardization and growth trend estimation. In: Cook, E. R, Kairiukstis, L. A. (eds.). Methods of Dendrochronology. Kluwer Academic Publishers, Dordrecht, pp. 104-123.

Enderle, R., Peters, F., Nakou, A., Metzler, B. (2013). Temporal development of ash dieback symptoms and spatial distribution of collar rots in a provenance trial of Fraxinus excelsior. Eur. J. For. Res., 132, 956-876.

Grissino-Mayer, H. D. (2001). Evaluating crossdating accuracy: A manual and tutorial for the computer program COFECHA. Tree-Ring Res., 57, 205-221.

Gu, L., Hanson, P. J., Post, W. M., Kaiser, D. P., Yang, B., Enami, R., Pallardy, S. G., Meyers, T. (2008). The 2007 Eastern US spring freeze: Increased cold damage in a warming world? BioScience, 58, 253-262.

Harris, I., Jones, P. D., Osborn, T. J., Lister, D. H. (2014). Updated high-resolution grids of monthly climatic observations - the CRU TS3.10 Dataset. Int. J. Climatol., 34, 623-642. 
Helama, S., Läänelaid, A., Raisio, J., Tuomenvirta, H. (2009). Oak decline in Helsinki portrayed by tree-rings, climate and soil data. Plant Soil, 319, 163-174.

Hickler, T., Vohland, K., Feehan, J., Miller, P.A., Smith, B., Costa, L., Giesecke, T., Fronzek, S., Carter, T.R., Cramer, W., Kuhn, I., Sykes, M. T. (2012). Projecting the future distribution of European potential natural vegetation zones with a generalized, tree species-based dynamic vegetation model. Global Ecol. Biogeogr., 21, 60-63.

Kirisits, T., Freinschlag, C. (2011). Ash dieback caused by Hymenoscyphus pseudoalbidus in a seed plantation of Fraxinus excelsior in Austria. $J$. Agric. Ext. Rural Dev., 4, 184-191.

Kowalski, T. (2006). Chalara fraxinea sp. Nov. associated with dieback of ash (Fraxinus excelsior) in Poland. For. Pathol., 36, 264-270.

La Porta, N., Capretti, P., Thomsen, I. M., Kasanen, R., Hietala, A. M., Von Weissenberg, K. (2008). Forest pathogens with higher damage potential due to climate change in Europe. Can. J. Plant Pathol., 30, 177-195.

Lizuma, L., Kḷaviņš, M., Briede, A., Rodinovs, V. (2007). Long-term changes of air temperature in Latvia. In: Kḷaviņš, M. (ed.). Climate Change in Latvia. University of Latvia, Riga, pp. 11-20.

Martin-Benito, D., Cherubini, P., del Rio, M., Canellas, I. (2008). Growth response to climate and drought in Pinus nigra Arn. trees of different crown classes. Trees-Struct. Funct., 22, 363-373.

Matisons, R., Elferts, D., Brūmelis, G. (2012). Changes in climatic signals of English oak tree-ring width and cross-section area of earlywood vessels in Latvia during the period 1900-2009. For. Ecol. Man., 279, 34-44.

Neuwirth, B., Esper, J., Schweingruber, F. H., Winiger, M. (2004). Site ecological differences to the climatic forcing of spruce pointer years from the Lötschental, Switzerland. Dendrochronologia, 21, 69-78.

Pallardy, S. G. (2008). Physiology of Woody Plants. Elsevier, London. 464 pp.

Pautasso, M., Dehnen-Schmutz, K., Holdenrieder, O., Pietravalle, S., Salama, N., Jeger, M. J., Lange, E., Hehl-Lange, S. (2010). Plant health and global change - some implications for landscape management. Biological Rev. Cambridge Philosoph. Soc., 85, 729-755.

Pliûra, A., Lygis, V., Suchockas, V., Bartkevičius, E. (2011). Performance of twenty four European Fraxinus excelsior populations in three Lithuanian progeny trials with a special emphasis on resistance to Chalara fraxinea. Baltic For., 17, 17-34
Ryan, M. G. (1990). Growth and maintenance respiration in stems of Pinus contorta and Picea engelmanii. Can. J. For. Res., 20, 48-57.

Sass-Klaassen, U., Sabajo, C.R., den Ouden, J. (2011). Vessel formation in relation to leaf phenology in pedunculate oak and European ash. Dendrochronologia, 29, 171-175.

Schweingruber, F. H. (1992). Dendrochronological information in pointer years and abrupt growth changes. In: Cook, E. R., Kairiukstis, L. A. (eds.). Methods of Dendrochronology. Kluwer Academic Publishers, Dordrecht, pp. 277-284.

Skovsgaard, J. P., Thomsen, I. M., Skovgaard, I. M., Martinussen, T. (2010). Associations between symptoms of dieback in even-aged stands of ash (Fraxinus excelsior L.). For. Pathol., 40, 7-18.

Speer, J. H. (2010). Fundamentals of Tree-ring Research. The University of Arizona Press, Tucson. 333 pp.

Thomsen, I. M., Skovsgaard, J. P. (2006). Crown dieback of ash: Climatic damage or fungal attack? Skoven, 38, 408-411 (in Danish).

Tierney, G. L., Fahey T. J., Groffman, P. M., Hardy, J. P., Fitzhugh, R. D. Driscoll, C. T. (2001). Soil freezing alters fine root dynamics in a northern hardwood forest. Biogeochemistry, 56, 175-190.

Timmermann, V., Børja, I., Hietala, A. M., Kirisits, T., Solheim, H. (2011). Ash dieback: Pathogen spread and diurnal patterns of ascospore dispersal, with special emphasis on Norway. EPPO Bull. (European and Mediterranean Plant Protection Organization Bulletin), 41, 14-20.

Tulik, M., Marciszewska, K., Adamczyk, J. (2010). Diminished vessel diameter as a possible factor in the decline of European ash (Fraxinus excelsior L.). Ann. For. Sci., 103, 1-8.

Tyree, M. T., Zimmermann, M. H. (2002). Xylem Structure and Ascent of Sap. Springer, Berlin. 304 pp.

Wigley, T. M. L., Briffa, K. R., Jones, P. D. (1984). On the average value of correlated time series, with applications in dendroclimatology and hydrometeorology. J. Climate Appl. Meteorol., 23, 201-213.

Zhang, S. Y. (1997). Variations and correlations of various ring width and ring density features in European oak: Implications in dendroclimatology. Wood Sci. Technol., 31, 63-72.

Zhu, X. B., Cox, R. M., Apr, P. A. (2000). Effects of xylem cavitation and freezing injury on dieback of yellow birch (Betula alleghaniensis) in relation to a simulated winter thaw. Tree Physiol., 20, 541-547.

Received 12 January 2016

\section{PARASTĀ OŠA AR ATŠKIIRĪGU VAINAGA STĀVOKLI GADSKĀRTU PLATUMA ZĪMĪGIE GADI UN TO SAISTĪBA AR METEOROLOGISKAJIEM FAKTORIEM}

Meteorologiisko faktoru saistības ar parastā oša (Fraxinus excelsior L. ) gadskārtu platumu (tree-ring width, TRW), kas auga Latvijas centrālajā un austrumu reğionā un bija ar atšḳirīgu vainaga stāvokli, novērtētas, izmantojot dendrohronoloǵijas metodes. Lai raksturotu TRW mainību, aprēķināti "Zīmīgo gadu” indeksi. Kopumā pozitīvo "zīmīgo gadu" skaits pārsniedza negatīvo gadu skaitu, norādot, ka ošu augšana ir bijusi apgrūtināta gan bojātajiem, gan vitālajiem kokiem. Saistības starp zīmīgo gadu sērijām un meteoroloğiskajiem faktoriem atšḳīās gan reǵionāli, gan lokāli. Audzēs Latvijas austrumu dạ̦ā $T R W$ galvenokārt ietekmēja pavasara (aprīlis-maijs) temperatūra (pozitīvi) un diennakts temperatūras amplitūda (negatīvi) gadskārtas veidošanās gadā, kā arī iepriekšējā gadā. Latvijas centrālajā dạ̣ā laikapstākḷi vasarā bija galvenie $T R W$ ietekmējošie meteoroloğiskie faktori. Temperatūrai un nokrišniem konstatēta pozitīva, bet temperatūras diennakts amplitūdai - negatīva ietekme. Novērotās saistības atšḳīrās bojātajiem un vitālajiem kokiem. Latvijas centrālajā daḷā bojātie koki bija papildus jutīgi pret temperatūru jūnijā un temperatūras amplitūdu jūlijā. Latvijas austrumu dạ̦ā, bojātie oši bija papildus jutīgi pret temperatūru maijā. Tomēr abos reǵionos arī vitālajiem kokiem novērotas tikai tiem specifiskas saistības ar meteoroloğiskajiem faktoriem, norādot, ka bojātie koki nav bijuši krasi jutīgāki pret meteoroloğiskajiem faktoriem. 